\title{
Citizenship in Cloud Cuckoo Land?
}

\author{
Rainer Bauböck
}

We are in the midst of a digital revolution that could transform societies worldwide as profoundly as the agrarian revolution of the Neolithic age and the industrial revolution of the $19^{\text {th }}$ century did. No doubt, new technologies will also deeply affect the structure and boundaries of political communities and the meaning of citizenship. Liav Orgad tells a hopeful story about the benefits of blockchain technology. It can serve to create an international legal identity for every human being and new forms of nonterritorial political community in which citizenship is based entirely on consent. I share Orgad's sense of excitement about the speed and depth of change that we are witnessing. But I am less optimistic about the future of citizenship.

\section{The progressive potential: providing global legal status and enabling global civil society}

Orgad's first suggestion is that digital technologies will make it possible to provide every human being with an international legal persona, a 'default lifelong identity and membership for every person, which cannot be waived or withdrawn' (original emphases). This would indeed be a major achievement. In less developed countries and autocratic regimes, millions of births are not registered. Unregistered persons are de facto stateless and cannot claim services or rights from governments that do not recognise them as nationals. ${ }^{1}$

Yet blockchain, the technology that he sees as most promising for this task, is not a tool to improve governments' administrative capacities. It is a decentralised ledger that is not under the control of any government or corporation. Individuals control themselves what their registered identity is (e.g. their chosen gender) and who gets access to their linked data (such as

1 For Africa see Manby, B. (2016), Citizenship Law in Africa. A Comparative Study. New York: Open Society Foundations, $3^{\text {rd }}$ edition, available at https:// www.opensocietyfoundations.org/sites/default/files/citizenship-law-africathird-edition-20160129.pdf 
health or education records). This is why Orgad sees in blockchain technology a potential 'to provide people with self-sovereign identity' (original emphasis).

There is an obvious tension between these two goals: providing every human being with an unalterable and unique identity, on the one hand, and providing them with sovereign control over their identity related data, on the other hand. Births and deaths must be registered by someone else than the individuals concerned. Presumably adult individuals, too, are constrained in their choices because they must not opt out by deleting their international legal identity or subvert the global registry by assuming that of another person. More importantly, governments will not be out of business. Even if the act of registration is certified in a decentralised ledger, governments must recognise it in order for individuals to enjoy legal statuses and rights that only states can grant.

Orgad seems to be aware of this tension when he writes that a global ID is not a status of world citizenship and that it would supplement rather than replace national citizenships assigned by governments. But he also wants to put it to uses that would undermine the international system of sovereign states as we know it. When Orgad suggests that all individuals could be represented equally in making international law, he must have some form of global federal democracy in mind, e.g. a 'peoples' assembly' enjoying colegislative powers with a body in which each state has one vote, as in the UN General Assembly. ${ }^{2}$

His main vision is, however, the emergence of alternative forms of political community at the sub-global level: cloud communities or virtual nations that individuals can join based on shared concerns or ascriptive identities that transcend the territorial boundaries of states. Orgad envisages two ways how these communities can come about: bottom up or top down. People concerned about global social justice could form cloud communities promoting this goal, whereas others may want to join a global ethnic or religious diaspora. The UN could initiate cloud communities that support its development or climate change goals, but also states or regions could set them up to empower their diasporas.

2 Proposals for a UN reform along these lines have been made since the 1990s. See Archibugi, D. (1993), 'The Reform of the UN and Cosmopolitan Democracy: A Critical Review', Journal of Peace Research 30 (3): 301-315. 
To me, these applications of cloud communities look like an expansion of civil society, of international organisations, or of traditional territorial polities into cyberspace, rather than like genuinely new forms of political community. If this is what they are, then cloud communities could provide great opportunities. They could mobilise individuals across the world for goals of global justice or climate protection. And they would provide new spaces for civil society in states that suppress individual liberty and oppress ethnic or religious minorities. I imagine that states and global corporations, even if they cannot control the underlying blockchain registries, will find ways to instrumentalise or hijack cloud communities for their own purposes, as they already do with the internet and social media. Autocrats have done so with new communication technologies ever since the invention of the printing press. Yet this is not my main worry. It would be wrong as well as futile to reject new technologies that enhance individual freedom because they can also be used to constrain it.

\section{The threat to democracy: should we be ruled by voluntary associations?}

My main worry is that cloud communities may provide new global spaces for citizenship as civic participation while undermining its foundation as equal membership in territorial polities. This tension emerges from contrasting mechanisms for determining membership in civil society and in political communities. Civil society is the realm of voluntary association in between the involuntary associations of families, firms and states. ${ }^{3}$ In contrast with a global ID, which would register another form of involuntary membership, that of belonging to the human species, cloud communities must be voluntary associations. Individuals sort themselves into such communities by applying for membership or opting out while communities enjoy collectively powers to determine the conditions for admission. A vibrant sphere of voluntary associations is an essential element of democratic citizenship. And in an increasingly interconnected world it is indeed highly desirable to expand civil society so that individuals can act as global citizens in voluntary associations that pursue global agendas.

But they can do so only because and insofar as they have a secure territorial citizenship that protects their fundamental rights and makes them

3 See Bauböck, R. (1996), 'Social and Cultural Integration in Civil Society', in R. Bauböck, A. Heller \& A. Zolberg (eds.), The Challenge of Diversity. Integration and Pluralism in Societies of Immigration, 67-132. Aldershot, UK: Avebury. 
equal members of a political community that most of them have not chosen to belong to. The social contract metaphor that has informed liberal thinking about citizenship since Hobbes, Locke and Rousseau is misleading in this respect. Citizenship as a legal status of membership in a territorial polity has never been based on consent. Citizenship in today's states is generally acquired at birth - either through birth in the territory or descent from citizen parents. Immigrants may opt in through applying for naturalisation but - as the word itself signals - they join a birthright community. Emigrants may opt out through renouncing their nationality, but they can generally do so only if they have already resided abroad for some time and have acquired another citizenship. The non-voluntary nature and automatic acquisition of citizenship are even stronger at local and regional levels. Local citizenship is, or should be, generally based on residence rather than birth. By taking up residence in another municipality I become a local citizen and acquire rights to be represented in local government. In an increasing number of democracies this principle of ius domicilii is also extended to foreign nationals who are granted voting rights in local elections. ${ }^{4}$ Finally, regional citizenship in federal states or supranational unions is automatically derived from nationality. I am a citizen of the province of Lower Austria and a citizen of the European Union because I am an Austrian national. Birthright, residence and derivation are three complementary ways how territorial polities determine who their citizens are. ${ }^{5}$ None of them is based on voluntary association.

But why should we not see cloud communities building on blockchain technology as finally realising the social contract ideal by enabling us to shed the coercive straightjacket of nonvoluntary citizenship and transforming all political communities into voluntary associations? My response is that this would be fatal for democracy. Already Aristotle knew that, unlike families, democratic polities are association of diverse individual. These have only one thing in common: a shared destiny that links the freedom and well-being of each to the collective freedom and good of all. The territorial bases and automatic attribution mechanisms of citizenship create political community among individuals that differ profoundly in their interests, identities and ideas about the common good. Democracy is a set of institutions and procedures that provide solutions to collective action problems and

4 Arrighi, J.-T. \& R. Bauböck (2017), ‘A multilevel puzzle. Migrants’ voting rights in national and local elections', European Journal of Political Research 56 (3): 619-639.

5 See Bauböck, R. (2017), Democratic Inclusion. A Pluralistic Theory of Citizenship. Manchester: Manchester University Press, 57-87. 
legitimacy for coercive government exercised over a set of individuals who have been thrown together in a territory instead of having chosen each other in a voluntary association.

Voluntary associations in civil society and territorial democracies are thus based on categorically different membership principles. Cloud communities could strengthen democratic citizenship if they contribute to expanding civil society to global scale. They would, however, undermine democracy if they took over the provision of public goods and functions of coercive government from territorial polities. Imagine what kind of cloud communities would be formed if these enjoyed powers similar to today's states. Individuals would sort themselves out into like-minded sets just as they do in the echo chambers of today's social media networks. The rich would form non-territorial polities that provide them with the best medical, educational and private security services worldwide without being taxed to finance adequate services also for the local poor. The dreams of nationalists of matching ethnocultural with political boundaries would finally come true if the latter are no longer territorial since, unlike territory, voluntary association is not a scarce resource. The boundaries of political communities would be constantly reshaped in efforts to get rid of minorities or lower classes who have become redundant in a digitalised economy.

This is in my views a dystopian rather than a utopian scenario. I do not think it is likely to happen any time soon, because states are powerful beasts that have been skilful in adapting to technological revolutions and using them for their purposes. I also think that most individuals are attached to territorial democracy and citizenship and will fight back politically against what they regard as excesses of globalisation. Unfortunately, they do so today often through voting for populist parties and politicians that promote an illiberal transformation of democracy. The task for liberal democrats is to strengthen the integration of territorial democracies by bridging the cleavage between mobile and globally oriented populations, on the one side, and immobile ones that experience a shrinking of their opportunities and lifeworlds, on the other side.

But maybe this is a period of transition and the next generations of digital natives will be much more footloose than today's sedentary majorities? A combination of a steep rise in global mobility with digital technologies empowering non-territorial political communities may make preserving territorial democracy and citizenship a hopeless goal. Individuals' primary political allegiances would then no longer be to a community of citizens rooted in a particular territory but to their self-selected cloud community. 
It may happen, but democracy would then separate individuals living next to each other instead of uniting them as equal citizens in spite of their differences. This is not going to be Aristophanes' happy cloud cuckoo land.

Open Access This chapter is licensed under the terms of the Creative Commons Attribution 4.0 International License (http://creativecommons.org/licenses/by/4.0/), which permits use, sharing, adaptation, distribution and reproduction in any medium or format, as long as you give appropriate credit to the original author(s) and the source, provide a link to the Creative Commons license and indicate if changes were made.

The images or other third party material in this chapter are included in the chapter's Creative Commons license, unless indicated otherwise in a credit line to the material. If material is not included in the chapter's Creative Commons license and your intended use is not permitted by statutory regulation or exceeds the permitted use, you will need to obtain permission directly from the copyright holder.

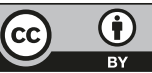

